\title{
Diverse clinical presentations of celiac disease in the same family
}

\author{
L. Rodrigo, S. Riestra ${ }^{1}$, D. Fuentes, S. González, A. López-Vázquez and C. López-Larrea \\ Service of Digestive Diseases and Immunology. Hospital Central de Asturias. ${ }^{~}$ Hospital Valle del Nalón. Oviedo. Spain
}

Rodrigo L, Riestra S, Fuentes D, González S, López-Vázquez A, López-Larrea C. Diverse clinical presentations of celiac disease in the same family. Rev Esp Enferm Dig 2004; 96: 612-619.

\begin{abstract}
We performed a family study to evaluate a total of 34 extended family members $(8$ siblings, 23 children and nephews, and 3 grandchildren) of an adult patient with celiac disease (CD), a 58year-old male with severe neurologic involvement manifested as myoclonias.

We found 3 other members affected with CD (a 44-year old sister, a 39-year old niece, and a 26-year old nephew). Two of them were completely asymptomatic and all had hypertransaminasemia. All exhibited a villous atrophy pattern of the duodenal mucosa ( 1 mild, 1 moderate, 1 severe). Overall family involvement was $11.8 \%(4 / 14)$

We wish to emphasize the need to perform extended family studies when diagnosing a case of $\mathrm{CD}$, since risk is not restricted to only first-degree relatives.
\end{abstract}

Key words: Clinical forms. Celiac disease. Familial study.

\section{INTRODUCTION}

Celiac disease (CD) is an enteropathy due to hypersensitivity to gluten that is characterized by a considerable heterogeneity of clinical presentations (1). Screening studies

Recibido: $31-10-03$

Aceptado: 10-02-04.

Correspondencia: Luis Rodrigo. Servicio de Aparato Digestivo. Hospital Central de Asturias. C/ Celestino Villamil, s/n. 33006 Oviedo. Telf.: 985 108 058. Fax: 985273 614. e-mail: lrodrigos@terra.es for $\mathrm{CD}$ in the general population have shown a high prevalence ( 1 of 100-300 people), and also a low rate of diagnosis worldwide (2,3). CD does not present only in children, but its onset may be delayed until adolescence or adulthood; in our environment sixty percent of patients with $\mathrm{CD}$, have been diagnosed in adulthood (4); some authors suggest that the majority of these cases are non-classical, or atypical forms of the disease (5). It is for this reason that, in order to increase the number of patients diagnosed, we should be aware of the non-classical clinical manifestations of the disease, and also perform serological screening in groups at higher risk (family of celiac patients, type 1 diabetes, etc.).

The families of celiac patients are one of the better characterized groups, as risk increases with relation to the genetic basis of the disease (6). Multiple studies have shown a high prevalence (2-18\%) of CD among first-degree relatives (7-10). This wide variation in results may be related to the diagnostic methods used (serology, clinical symptoms, intestinal permeability or intestinal biopsy), and the criteria employed for its diagnosis (villous atrophy, latent forms). Currently, serological screening using tissue anti-transglutaminase antibodies (anti-tTG) is the method of choice in the search for new cases in risk groups.

We present here the results of an extended family study, carried out for a patient with $\mathrm{CD}$ and neurological manifestations; we emphasise the non-classical forms of presentation of this disease in affected relatives.

\section{CASE REPORTS}

We assessed a total of 34 extended family members ( 8 siblings, 23 children and nephews, and 3 grandchildren) of an adult patient (a 58-year-old male) with $\mathrm{CD}$ and severe neurological symptoms (index case) (Fig. 1). A clinical history, and a complete physical exploration and laboratory study were performed to all family members, which included: hemogram, coagulation tests, general biochemistry, liver enzymes, serum iron, folic acid, and vitamin B-12 levels, 


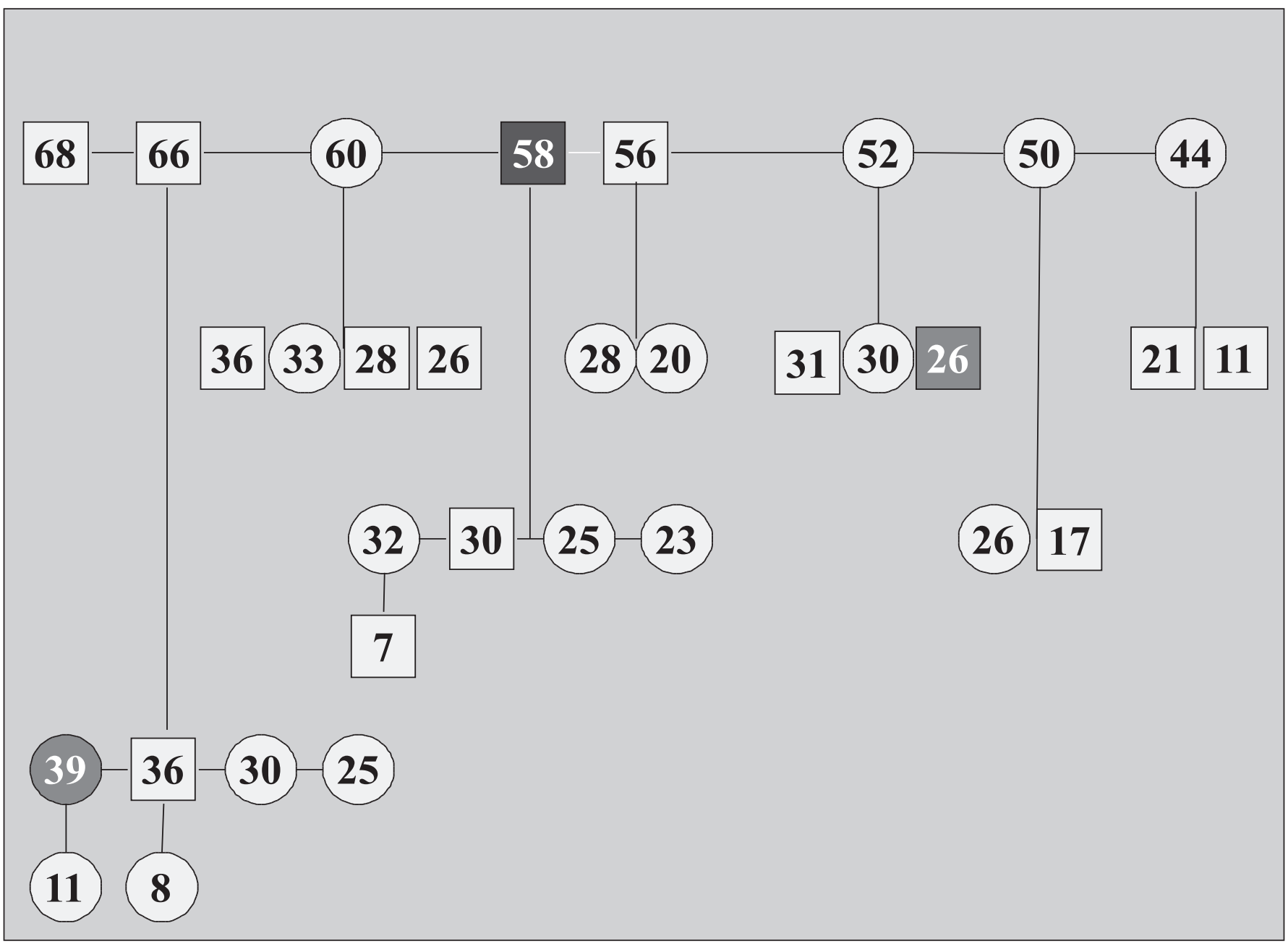

Fig. 1.- Familial tree of studied members (age in years).

Árbol genealógico de familiares estudiados (edad en años).

TSH, and anti-thyroid antibodies. For the serological screening of CD, we determined antigliadin IgA (AGA), anti-endomysium IgA (EMA), and human-tissue anti-transglutaminase IgA (anti-tTG) antibodies, and HLA-II typing was performed in all cases.

In relatives in whom clinical and laboratory alterations were found, specific studies were carried out. When celiac disease was suspected, an upper digestive endoscopy with multiple duodenal biopsies, was performed.

We describe here the clinical characteristics of four patients with CD from the same family, which represents an overall familial involvement of $11.8 \%$ (4 of 34).

\section{Case 1 (index case)}

A 58-year-old male diagnosed with CD three years earlier underwent studies for a 1-year-standing clinical picture of diarrhea and abdominal pain. HLA-DQ2 heterodimer was positive, and an intestinal biopsy showed complete villous atrophy (Marsh grade 3c). Following two months on a gluten-free diet (GFD), digestive symptoms subsided.

Eighteen months ago the patient began to experience frequent, severe myoclonus. On neurological exploration an inexpressive face, peribucal fasciculations, generalized bradykinesia -more marked in the right half of the body, with preserved strength- and reflex myoclonus in the right lower limb were unveiled. Hematological and biochemical studies were normal. AGA was negative, while EMA and anti-tTG were positive with low titers; other antibodies detected were p-ANCA (1/80) and anti-smooth muscle (1/80). A second duodenal biopsy showed slight histological improvement with partial villous atrophy (Marsh grade 3a), and a considerable inflammatory infiltrate within the lamina propria.

A study of CSF cells and proteins was normal; CSF culture was negative. A brain magnetic resonance imaging (MRI) scan showed no significant anomalies. Electroencephalographic activity was normal. Electromyographic activity as recorded from the right tibial muscle showed sharp 
wave paroxysms of very low voltage in central cerebral regions, and myoclonic reflexes on the right leg. Neurological assessment showed a general alteration of cognitive functions, those of language and memory being better preserved, which suggested a predominant involvement of the right cerebral hemisphere at a parietal level, accompanied by subcortical dysfunction.

The patient was treated with clonazepan, pyracetam, azathioprine and two plasmapheresis sessions, but no positive response was elicited. Neurological involvement progressed, and the patient presented with disorientation, disarthria and myoclonus, and difficulty for walking unaided. Finally, the patient died from aspiration pneumonia two years after the onset of neurological involvement.

\section{Case 2}

A 44-year-old female, a sister of the index case, presented with a history of iron deficiency anemia and occasional diarrhea. Laboratory studies showed: Hb: $11.8 \mathrm{~g} / \mathrm{dl}(\mathrm{MCV}=$ 71.7), $\mathrm{AST}=481(\mathrm{~N}<31 \mathrm{U} / \mathrm{l}), \mathrm{ALT}=754(\mathrm{~N}<31 \mathrm{U} / \mathrm{l}), \mathrm{FA}$ $=722(\mathrm{~N}<280 \mathrm{U} / \mathrm{l})$, and GGT $=134(\mathrm{~N}<32 \mathrm{U} / \mathrm{l})$. Anti-HCV and anti-HB core antibodies, and non-organ specific antibodies (ANA, SMA, AMA, LKM-1) were negative. In this patient EMA (1/40) and anti-tTG $(30 \mathrm{U} / \mathrm{mL})$ were detected, and HLA-DQ2 heterodimer was positive. A duodenal biopsy showed complete villous atrophy (Marsh grade 3c).

The patient was prescribed a GFD, and a remission of diarrhea and normalization of hemoglobin levels and liver enzymes, were observed at 3 months.

\section{Case 3}

A 39-year-old woman, a niece of the previous two cases, was completely asymptomatic, and exhibited normal biochemical tests, except for a minimal elevation of ALT $=65$ $(\mathrm{N}<31 \mathrm{U} / \mathrm{l})$ and GGT = $146(\mathrm{~N}<39 \mathrm{U} / \mathrm{l})$. Anti-HCV antibodies, anti-HB core, ANA, AMA, SMA and LKM1 were all negative. With respect to the serological study of $\mathrm{CD}$, EMA (1/10) and anti-tTG (14 U/ml) were detected. HLADQ2 heterodimer was negative. A duodenal biopsy showed partial villous atrophy (Marsh grade 3a).

After 6 months on a GFD, liver function tests returned to normal and a serology of CD was negative.

\section{Case 4}

A 26-year-old male, a nephew of cases 1 and 2 above, and a cousin of case 3, was completely asymptomatic. Laboratory studies showed a slight elevation of AST $=42(\mathrm{~N}<$ $31 \mathrm{U} / \mathrm{l})$ and $\mathrm{ALT}=72(\mathrm{n}<31 \mathrm{U} / \mathrm{l})$, and also a decrease in serum folic acid $=2(\mathrm{~N}>3 \mathrm{ng} / \mathrm{ml})$, without anemia. EMA $(1 / 320)$ and anti-tGT (> $200 \mathrm{U} / \mathrm{ml})$ were positive, and the HLA-DQ2 heterodimer was positive. A duodenal biopsy showed mild villous atrophy (Marsh grade $3 \mathrm{~b}$ ).

Similarly to the other family members with CD, starting on a gluten-free diet was accompanied by a disappearance of laboratory alterations and a negativization of EMA and anti-tTG antibodies. A summary of these four cases is shown in table I.

\section{DISCUSSION}

The first report on a familial distribution of CD was made in 1935 (11); currently, it is known that a $70 \%$ concordance exists for $\mathrm{CD}$ in monozygotic twins, compared to $11 \%$ in dizygotic twins (12), which provides evidence for a strong genetic basis of this disease. The most powerful genetic association is with class II HLA alleles, which code for the DQ2 heterodimer (13). However, these are also present in $20 \%$ of the general population (10), for which reason other genetic or environmental factors, seem to be needed for the development of the disease. Moreover, our group observed that a class I HLA gene, the MICA 5.1 allele, is associated with non-classical forms of celiac disease, in subjects with the high-risk DQ2 heterodimer (14).

Table I. Clinical characteristics of relatives with celiac disease

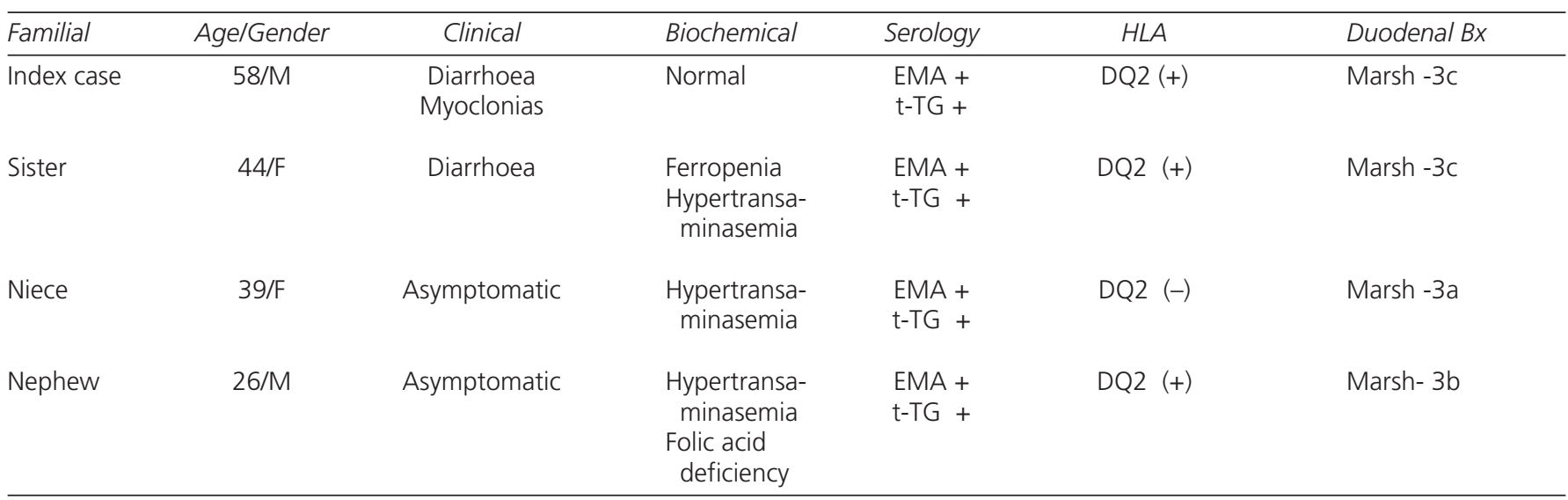

M = male; F = female; EMA = anti-endomysial antibodies; t-TG = anti-transglutaminase antibodies; Bx = biopsy; Marsh-3a: mild atrophy; Marsh-3b: moderate atrophy; Marsh-3c: severe atrophy. 
The first aspect we would like to highlight in the current study is the high prevalence of CD in this same family $(11.8 \%)$. According to the degree of familial relationship, we have detected cases among brothers/sisters and nephews of the index case, which supports the need for carrying out extended familial studies, so that no cases are left undiagnosed within the same family. Another aspect we wish to emphasize is that two of the family members with CD were asymptomatic, which supports the need for serological studies in all extended family members, as we cannot rely on the presence of symptoms, in order to suspect the disease. The most efficient diagnostic approach should include a duodenal biopsy in all extended family members with positive anti-tTG antibodies, since it has been demonstrated that up to $92.3 \%$ of such family members can be diagnosed. However, the presence of mild forms of the disease among family members with a negative serology has been suggested by other authors (15), but with atypical symptoms and/or biochemical changes. Therefore we must bear in mind, that similarly to that which occurs in clinical practice, when faced with a clinical suspicion of CD, the "gold standard" is duodenal biopsy, regardless of serological results.

Up to $8 \%$ of CD cases can be associated with neurological symptoms, mainly cerebellar ataxia, epilepsy, and peripheral neuropathy. Patients with celiac disease who have neurological signs do not usually present with a picture of digestive disease, since the diagnosis of hypersensitivity to gluten is usually performed late in these cases. Knowledge of $\mathrm{CD}$ is important when neurological involvement coexists, because the introduction of a GFD during the first 6 months can lead to its improvement or disappearance. The pathogenesis of neurological involvement in $\mathrm{CD}$ is not well known, but it has been related to an autoimmune origin. In celiac patients with neurological symptoms the presence of anti-Purkinje cell and anti-CNS neurons antibodies has been shown $(16,18)$.

An association between $\mathrm{CD}$ and myoclonus has been previously reported, and is characterized, as in our index case, by having its onset in adulthood and several years after the diagnosis of CD $(19,20)$. Regarding the cause of myoclonus, it is known that, although of cortical origin, this condition is generally located in the cerebellum (19). In our patient the myoclonus appeared several years after the diagnosis of CD, and while the patient was on a GFD. However, the persistence of the enteropathy is indicative of lack of compliance with the diet, which could explain the appearance of complications. Similar to other cases, no response was seen to prescribed treatments, and the rapid evolution of the neurological picture toward an invalidating form in our patient was striking; its consequences eventually led to the patient's death.

In three of our family members with liver disease, the most common biochemical change was an increase in serum transaminase levels. On diagnosis, approximately $30 \%$ of celiac patients have altered liver function tests, their morphological substrate being a nonspecific reactive hepatitis $(21,22)$. As in our cases, the initiation of a GFD was followed by a normalization of biochemical changes, for which reason the performance of aggressive diagnostic tests such as liver biopsy, is not necessary. Since hypersensitivity to gluten is the cause of 4.4-9\% of cryptogenic hypertransaminasemias (23-25), we believe that, within the diagnostic protocol of this biochemical change, a serological study of CD should be included.

In conclusion, we wish to emphasize here the need to perform extended family studies when diagnosing a case of $\mathrm{CD}$, since risk is not only limited to first-degree relatives. Furthermore, we would also like to draw attention to the frequent development of atypical or asymptomatic forms among family members of celiac patients. Thus, the importance of performing studies in relatives will increase the number of patients diagnosed with $\mathrm{CD}$, within this wellcharacterized risk group.

\section{REFERENCES}

1. Farrell RJ, Kelly CP. Celiac sprue. N Engl J Med 2002; 346: 180-8.

2. Riestra S, Fernández E, Rodrigo L, García S, Ocio G. Prevalence of coeliac disease in the general population of Northern Spain. Strategies of serological screening. Scand J Gastroenterol 2000; 35: 398402.

3. Mäki M, Mustalahti K, Kokkonen J, Kulmala P, Haapalahti M, Karttunen T, et al. Prevalence of celiac disease among children in Finland. N Engl J Med 2003; 348: 2517-24.

4. Riestra S, Fernández E, Bousoño C, Rodrigo L. Enfermedad celíaca del adulto. Gastroenterol Hepatol 2001; 24: 515.

5. Ivarsson A, Persson LA, Juto P, Peltonen M, Suhr O, Hernell O. High prevalence of undiagnosed coeliac disease in adults: a Swedish population-based study. J Intern Med 1999; 245: 63-8.

6. Schuppan D. Current concepts of coeliac disease pathogenesis. Gastroenterology 2000; 119: 234-42

7. Stenhammar L, Brandt A, Wagermark J. A family study of celiac disease. Acta Paediatr Scand 1982; 71: 625-8.

8. Mäkki M, Holm K, Lipsanen V, Hällström O, Viander M, Collin P, et al. Serological markers and HLA genes among healthy first-degree relatives of patients with celiac disease. Lancet 1991; 338: 1350-3.

9. Bonamico M, Mariani P, Mazzilli MC, Triglione P, Lionetti P, Ferrante $\mathrm{P}$, et al. Frequency and clinical pattern of celiac disease among sibling of celiac children. J Pediatr Gastroenterol Nutr 1996; 23: 15963.

10. Farré C, Humbert P, Vilar P, Varea V, Aldeguer X, Carnicer J, et al. Serological markers and HLA-DQ2 haplotype among first-degree relatives of celiac patients. Dig Dis Sci 1999; 44: 2344-9.

11. Thaysen TEH. Ten cases of idiopathic steatorrhea. Q J Med 1935; 4: 359-65.

12. Greco L, Romino R, Coto I, Cosmo ND, Percopo S, Maglio M, et al The first large population based twin study of coeliac disease. Gut 2002; 50: 624-8.

13. Sollid LM, Thorsby E. HLA susceptibility genes in celiac disease: genetic mapping and role in pathogenesis. Gastroenterology 1993; 105: 910-22.

14. López-Vázquez A, Rodrigo L, Fuentes D, Riestra S, Bousoño C, García-Fernández S, et al. MHC class I chain related gene A (MICA) modulates the development of coeliac disease in patients with the high risk heterodimer DQA1*501/DQB1*201. Gut 2002; 50: 336-40.

15. Rostami K, Mulder CJJ, van Overbeek FM, Kerckhaert J, Meijer JWR, von Blomberg MBE, et al. Should relatives of coeliacs with mild clinical complaints undergo a small-bowel biopsy despite negative serology? Eur J Gastroenterol Hepatol 2000; 12: 51-5.

16. Volta U, De Giorgio R, Petrolini N, Stanghellini V, Barbara G, Granito A, et al. Clinical findings and anti-neuronal antibodies in coeliac disease with neurological disorders. Scand J Gastroenterol 2002; 37: 1276-81.

17. Hadjivassiliou M, Gibson A, Davies-Jones GAB, Lobo AJ, Stephenson AJ, Milford-Ward A. Does cryptic gluten sensitivity play a part in neurological illness? Lancet 1996; 347: 369-71. 
18. Hadjivassiliou M, Boscolo S, Davies-Jones GAB, Grünewald RA, Not T, Sanders DS, et al. The humoral response in the pathogenesis of gluten ataxia. Neurology 2002; 58: 1221-6.

19. Bhatia KP, Browm P, Gregory R, Lennox GG, Manji H, Thompson $\mathrm{PD}$, et al. Progressive myoclonic ataxia associated with celiac disease. The myoclonus is of cortical origin, but the pathology is in the cerebellum. Brain 1995; 118: 1087-93.

20. Mumford CJ, Fletcher NA, Ironside JW, Warlow CP. Progressive ataxia, focal seizures, and malabsorption in a 41 year old woman. J Neurol Neurosurg Psychiatry 1996; 60: 225-30.

21. S Riestra, E Fernández, L Rodrigo. Afectación hepática en la enfermedad celíaca. Rev Esp Enferm Dig 1999; 91: 846-52.
22. Jacobsen MB, Fausa O, Elijo K, Schrumpf E. Hepatic lesions in adult coeliac disease. Scand J Gastroenterol 1990; 25: 656-62.

23. Volta U, de Franceschi L, Lari F, Molinaro N, Zoli M, Bianchi FB. Coeliac disease hidden by cryptogenic hypertransaminasaemia. Lancet 1998; 352: 26-9.

24. Bardella MT, Vecchi M, Conte D, Del Ninno E, Fraquelli M, Pacchetti $\mathrm{S}$, et al. Chronic unexplained hypertransaminasaemia may be caused by occult celiac disease. Hepatology 1999; 29: 654-7.

25. Vivas S, Ruiz de Morales JM, Martínez J, González MC, Martín S, Martín J, et al. Human recombinant anti-transglutaminase antibody testing is useful in the diagnosis of silent coeliac disease in a selected group of at-risk patients. Eur J Gastroenterol Hepatol 2003; 15: 479-83.

\title{
Diversas formas clínicas de presentación de la enfermedad celiaca dentro de la misma familia
}

\author{
L. Rodrigo, S. Riestra', D. Fuentes, S. González, A. López-Vázquez y C. López-Larrea \\ Servicio de Aparato Digestivo. Hospital Central de Asturias. ${ }^{~} H o s p i t a l$ Valle del Nalón. Oviedo
}

\section{RESUMEN}

Presentamos un estudio familiar de enfermedad celiaca, en el que se estudiaron un total de 34 miembros ( 8 hermanos, 23 hijos y sobrinos y 3 nietos) de un paciente adulto varón de 58 años con enfermedad celiaca (EC) complicada con afectación neurológica manifestada como mioclonías.

Encontramos 3 miembros más afectos de EC (1 hermana de 44, 1 sobrina de 39 y un sobrino de 26 años). Dos de ellos se encontraban completamente asintomáticos y todos presentaban hipertransaminasemia. Todos tenían atrofia de la mucosa duodenal (1 leve, 1 moderada y 1 importante). La afectación global familiar fue del 11,8\% (4/14).

Resaltamos la importancia de realizar estudios familiares extensos ante todo nuevo diagnóstico de EC, por la elevada incidencia de agregación familiar y predominio de formas asintomáticas y señalar que el riesgo no está limitado únicamente a familiares de primer grado.

Palabras clave: Formas clínicas. Enfermedad celiaca. Estudio familiar.

\section{INTRODUCCIÓN}

La enfermedad celiaca (EC) o enteropatía por sensibilidad al gluten se caracteriza por una gran heterogeneidad en sus formas de presentación clínica (1). Los estudios de cribado de enfermedad celiaca en población general, han de- mostrado una elevada prevalencia de la misma ( 1 de cada 100-300 personas), así como una baja tasa de diagnósticos $(2,3)$. La enfermedad celiaca no se presenta únicamente en la edad pediátrica, ya que el inicio de la misma puede retrasarse hasta edades juveniles o adultas; en nuestro medio, el $60 \%$ de pacientes con enfermedad celiaca han sido diagnosticados en edad adulta (4); algunos autores sugieren que la mayoría de estos casos se trata de formas no clásicas o atípicas de la enfermedad (5). Es por ello que, para aumentar el número de pacientes diagnosticados, debamos conocer las manifestaciones clínicas no clásicas de la enfermedad, asî como realizar cribado serológico a los grupos de mayor riesgo (familiares de celiacos, diabéticos tipo I, etc.).

Los familiares de los pacientes celiacos son uno de los grupos mejor caracterizados, estando el riesgo elevado en relación con la base genética de la enfermedad (6). Múltiples estudios han demostrado una elevada prevalencia (2$18 \%$ ) de enfermedad celiaca entre familiares (7-10). Esta amplia variación en los resultados, se ha puesto en relación con el método diagnóstico utilizado (serología, clínica, permeabilidad intestinal o biopsia intestinal), y con los criterios usados para diagnosticar la misma (atrofia vellositaria, formas latentes). Actualmente, el cribado serológico con la determinación de los anticuerpos antitransglutaminasa tisular (anti-TGt), constituye el método de elección para la búsqueda de nuevos casos en los grupos de riesgo.

En el presente trabajo presentamos los resultados de un amplio estudio familiar llevado a cabo a partir de un paciente con enfermedad celiaca y manifestaciones neurológicas; 
destacamos las formas de presentación no clásicas de la enfermedad en los familiares afectos.

\section{CASOS CLÍNICOS}

Evaluamos un total de 34 familiares ( 8 hermanos, 23 hijos y sobrinos y 3 sobrinos nietos) de un paciente adulto con enfermedad celiaca y síntomas neurológicos graves (caso índice). A todos los individuos se les realizó una historia clínica y exploración física completa, así como un estudio analítico que incluía: hemograma, coagulación, bioquímica general y enzimas hepáticos, niveles séricos de ferritina, ácido fólico, vitamina B-12, IgA total y TSH. Para el cribado serológico de la enfermedad celiaca determinamos los anticuerpos anti-gliadina $\operatorname{IgA}$, anti-endomisio IgA y anti-transglutaminasa tisular humana IgA y estudio genético HLA-II.

En los familiares en los que se detectaban alteraciones clínicas o analíticas, se realizaban los estudios específicos para filiar las mismas. Cuando existía sospecha clínica, analítica y/o serológica (anticuerpos antiendomisio y/o antitransglutaminasa tisular positivos) de EC, realizamos una endoscopia digestiva alta, con toma de múltiples biopsias duodenales.

A continuación describimos las características clínicas de los 4 pacientes con enfermedad celiaca, encontrados en la misma familia, lo cual supone una afectación familiar del $11,8 \%$ (4 de 34$)$.

\section{Caso 1 (caso índice)}

Varón de 58 años de edad, diagnosticado 3 años antes de enfermedad celiaca, tras los estudios practicados por clínica de diarrea y dolor abdominal de un año de evolución. El heterodímero HLA-DQ2 fue positivo y la biopsia intestinal mostró una atrofia vellositaria total (grado 3c de Marsh). Tras retirar el gluten de la dieta, se objetivó la desaparición de la clínica digestiva.

Hace 1,5 años, el paciente comenzó con mioclonias frecuentes e intensas. En la exploración neurológica destacaba la presencia de fasciculaciones peribucales, facies inexpresiva, bradicinesia generalizada, más marcada en hemicuerpo derecho, con fuerza conservada y mioclonías reflejas en miembro inferior derecho. Los estudios hematológicos y bioquímicos fueron normales. Los anticuerpos anti-gliadina fueron negativos, mientras que los anticuerpos anti-endomisio y antitransglutaminasa eran positivos a título bajo (1/10 y $13 \mathrm{U} / \mathrm{ml}$, respectivamente); otros autoanticuerpos detectados eran los p-ANCA (1/80) y los anti-músculo liso (1/80). Una nueva biopsia duodenal mostró una ligera mejoría histológica, persistiendo una atrofia vellositaria parcial (grado 3a), así como un importante infiltrado inflamatorio en la lámina propia.

El estudio de células y proteínas del LCR fue normal; el cultivo del mismo fue negativo. Una RMN cerebral no mostró anomalías significativas. El registro de la actividad cerebral mediante EEG fue completamente normal. El estudio electromiográfico realizado en la pierna derecha, mostró la presencia de paroxismos punta-onda, de muy bajo voltaje, que se observaron en las regiones centrales. Se trata de un registro de mioclonías reflejas. La evaluación neuropsicológica mostró una alteración general de las funciones cognitivas, estando más preservado el lenguaje y la memoria. Todo ello sugiere una afectación predominante del hemisferio cerebral derecho, a nivel parietal, acompañado de disfunción subcortical.

El paciente fue tratado con clonazepán, piracetam, azatioprina y plasmaféresis, sin obtenerse una respuesta positiva. La afectación neurológica progresó, presentando el paciente un cuadro de desorientación, disartria y mioclonías, con imposibilidad para la deambulación. Finalmente, el paciente falleció como consecuencia de una neumonía por aspiración, dos años después del comienzo de la afectación neurológica.

\section{Caso 2}

Mujer de 44 años de edad, hermana del caso índice, con antecedentes de anemia ferropénica y diarrea ocasional. En los estudios analíticos destacaban una $\mathrm{Hb}: 11,8 \mathrm{~g} / \mathrm{dl}$ $(\mathrm{VCM}=71,7), \mathrm{AST}=481(\mathrm{~N}<31 \mathrm{U} / \mathrm{l}), \mathrm{ALT}=754(\mathrm{~N}<31 \mathrm{U} / \mathrm{l})$, $\mathrm{FA}=772(\mathrm{~N}<280 \mathrm{U} / \mathrm{l})$ y $\mathrm{GGT}=134(\mathrm{~N}<32 \mathrm{U} / \mathrm{l})$. Los anticuerpos anti-VHC y antiHB-core, así como los autoanticuerpos no órgano específicos (ANA, AML, AMA y LKM-1) fueron negativos. En esta paciente se detectaron anticuerpos antiendomisio (1/40) y anti-transglutaminasa $(30 \mathrm{U} / \mathrm{ml})$, y el heterodímero HLA-DQ2 fue positivo. El estudio de la mucosa intestinal mostró una atrofia vellositaria total (grado 3c).

Con el diagnóstico de sospecha de enfermedad celiaca, la paciente comenzó una dieta sin gluten, observándose la desaparición de la diarrea y la normalización de las cifras de hemoglobina y enzimas hepáticos a los 3 meses.

\section{Caso 3}

Mujer de 39 años, sobrina de los anteriores, asintomática, que presentaba estudios bioquímicos normales, excepto una mínima elevación de la $\mathrm{ALT}=65(\mathrm{~N}<31 \mathrm{U} / \mathrm{l})$ y de la GGT $=146(\mathrm{~N}<39 \mathrm{U} / \mathrm{l})$; los anticuerpos anti-VHC, anti-HBcore, ANA, AMA, AML y LKM1 fueron negativos. Respecto al estudio serológico de enfermedad celiaca, se detectaron anticuerpos anti-endomisio (1/10) y anti-transglutaminasa tisular (14 U/ml); el heterodímero HLA-DQ2 fue negativo. La biopsia duodenal mostró una atrofia parcial de las vellosidades intestinales (grado 3a).

Tras la supresión del gluten de la dieta la paciente sigue asintomática, se han normalizado las pruebas hepáticas y se han negativizado los anticuerpos antiendomisio y antitransglutaminasa tisular.

\section{Caso 4}

Varón de 26 años, sobrino de los dos primeros y primo de la anterior, asintomático, en quien se detecta una mínima 
Tabla I. Características clínicas de los familiares afectos con enfermedad celiaca

\begin{tabular}{|c|c|c|c|c|c|c|}
\hline Parentesco & Edad/Sexo & Clínica & Bioquímica & Serología & $H L A$ & Biop.duodenal \\
\hline Caso índice & $58 / M$ & $\begin{array}{c}\text { Diarrea } \\
\text { Mioclonías }\end{array}$ & Normal & $\begin{array}{l}\mathrm{AEM}+ \\
\mathrm{t}-\mathrm{TG}+\end{array}$ & DQ2 (+) & $\begin{array}{c}\text { Atrofia marcada } \\
(3 c)\end{array}$ \\
\hline Hermana & $44 / F$ & Diarrea & $\begin{array}{l}\text { Ferropenia } \\
\text { Hipertransa- } \\
\text { minasemia }\end{array}$ & $\begin{array}{l}\mathrm{AEM}+ \\
\mathrm{t}-\mathrm{TG}+\end{array}$ & DQ2 (+) & $\begin{array}{l}\text { Atrofia marcada } \\
\qquad(3 c)\end{array}$ \\
\hline Sobrina & $39 / F$ & Asintomática & $\begin{array}{c}\text { Hipertransa- } \\
\text { minasemia }\end{array}$ & $\begin{array}{l}\mathrm{AEM}+ \\
\mathrm{t}-\mathrm{TG}+\end{array}$ & DQ2 (-) & $\begin{array}{c}\text { Atrofia leve } \\
(3 a)\end{array}$ \\
\hline Sobrino & $26 / M$ & Asintomático & $\begin{array}{l}\text { Hipertransa- } \\
\text { minasemia } \\
\text { Deficiencia } \\
\text { de ácido fólico }\end{array}$ & $\begin{array}{l}\mathrm{AEM}+ \\
\mathrm{t}-\mathrm{TG}+\end{array}$ & DQ2 (+) & $\begin{array}{c}\text { Atrofia moderada } \\
(3 b)\end{array}$ \\
\hline
\end{tabular}

$\mathrm{M}$ = masculino; $\mathrm{F}$ = femenino; $\mathrm{AEM}$ = anticuerpos anti-endomisio; $\mathrm{t}-\mathrm{TG}$ = anticuerpos anti-transglutaminasa tisular.

elevación de la AST=42 (N<31 U/1) y ALT=72 (N<31 U/1), así como un descenso de los niveles séricos de ácido fólico, 2 (N>3 ng/ml), sin anemia. Los anticuerpos EMA (1/320) y anti-tTG (> $200 \mathrm{U} / \mathrm{ml})$ fueron positivos, así como el heterodímero HLA-DQ2. La biopsia duodenal mostró una atrofia vellositaria moderada (grado 3 b).

Al igual que en el resto de familiares celiacos, la supresión del gluten se acompañó de la desaparición de las alteraciones analíticas y de la negativización de los anticuerpos anti-endomisio y anti-transglutaminasa tisular. Se muestra un esquema de los cuatro casos en la tabla I.

\section{DISCUSIÓN}

La primera comunicación sobre el carácter familiar de la enfermedad celiaca data de 1935 (11); actualmente se sabe que existe un $75 \%$ de concordancia para la enfermedad celiaca entre gemelos monocigotos, frente a un $11 \%$ entre gemelos dicigotos (12), lo cual es evidencia para una fuerte carga genética de la enfermedad. La asociación genética más potente es con los alelos HLA de clase II, DQA1*501 y DQB1*201, que codifican el heterodímero DQ2 (13); sin embargo, estos están presentes también en un $20 \%$ de la población general (10), por lo que parece demostrada la necesidad de otros factores genéticos o ambientales en el desarrollo de la enfermedad. Así, en nuestro grupo, hemos observado como un gen HLA de clase I, el alelo MICA 5.1, se asocia a formas no clásicas de enfermedad celiaca en sujetos con el heterodímero de alto riesgo DQ2 (14).

El primer aspecto que nos gustaría destacar del presente trabajo, es la elevada prevalencia de enfermedad celiaca en una misma familia (4 de 34; 11,8\%); en alguna publicación, hasta el $2,6 \%$ de las familias estudiadas tenían tres o más miembros con enfermedad celiaca. Según el grado de relación familiar, hemos detectado casos entre hermanos y sobrinos del caso índice, lo cual apoya la necesidad de hacer estudios familiares amplios para no dejar sin diagnosticar casos dentro de una misma familia. Otro aspecto a destacar es que 2 de los 4 familiares con enfermedad celiaca estaban asintomáticos, lo cual apoya la necesidad de hacer estudio serológico a todos los familiares, no pudiendo basarnos únicamente en la presencia de síntomas para sospechar la enfermedad. El abordaje diagnóstico más eficiente, debe incluir la biopsia intestinal en todos los familiares con anticuerpos anti-transglutaminasa, pues así se ha demostrado que se diagnostican hasta el 92,3\% de los casos familiares; no obstante, se ha sugerido por otros autores (15), la presencia de formas leves de la enfermedad entre familiares con serología negativa, pero con síntomas atípicos y/o alteraciones bioquímicas. Por tanto, debemos de tener en cuenta que, al igual que ocurre en la práctica clínica, ante la sospecha de enfermedad celiaca la "prueba oro" es la biopsia intestinal, independientemente del resultado de la serología.

La enfermedad celiaca se puede asociar hasta en un $8 \%$ de los casos a síntomas neurológicos, fundamentalmente ataxia cerebelosa, epilepsia y neuropatía periférica. Los pacientes con enfermedad celiaca con manifestaciones neurológicas, no suelen presentar clínica digestiva, de ahí que el diagnóstico de la sensibilidad al gluten sea generalmente tardío en estos casos. Es importante el reconocimiento de la enfermedad celiaca, puesto que la supresión del gluten precozmente tras el inicio de los síntomas neurológicos puede causar su mejoría o desaparición. La patogenia de la afectación neurológica en la enfermedad celiaca no es bien conocida, pero se ha relacionado con un origen autoinmune; en pacientes celiacos con síntomas neurológicos, se ha demostrado la presencia de anticuerpos anti-células de Purkinje y anti-neuronas del SNC en suero (16-18).

La asociación entre enfermedad celiaca y mioclonías ya ha sido comunicada previamente y se caracteriza, como en nuestro caso índice, por su inicio en la edad adulta y años después del diagnóstico de la enfermedad celiaca $(19,20)$; en cuanto a la causa de las mioclonías se sabe que aunque su origen sea cortical, la patología generalmente se localiza a nivel del cerebelo (19). En nuestro paciente las mioclonías aparecieron varios años después del diagnóstico de enfermedad celiaca, y mientras seguía una dieta sin gluten; no obstante, la persistencia de lesión histológica en la mucosa intestinal, pudiera estar relacionada con una falta de 
cumplimiento del tratamiento dietético, lo cual podría explicar, en cierta manera, la aparición de las complicaciones neurológicas; aunque ciertamente, no se realizaron otras pruebas que descartaran la existencia asociada de otra enteropatía. Al igual que en otros casos de enfermedad celiaca con afectación neurológica asociada, no hubo respuesta a los tratamientos pautados, siendo además destacable en nuestro paciente, la rápida evolución del cuadro neurológico hacia una forma invalidante, que fue causa de su fallecimiento.

En tres de nuestros familiares con enfermedad hepática, la alteración bioquímica más llamativa fue una hipertransaminasemia. Al diagnóstico, aproximadamente un $30 \%$ de los celiacos tienen alteración en las pruebas hepáticas, siendo el sustrato morfológico de la misma una hepatitis reactiva inespecífica $(21,22)$; como en nuestros casos, la instauración de una dieta sin gluten se sigue de la normalización de las alteraciones bioquímicas, por lo que no es preciso la realización de pruebas diagnósticas agresivas como la biopsia hepática. Dado que la sensibilidad al gluten es causa de un 4,4-9\% de hipertransaminasemias criptogenéticas (23-25), creemos que, dentro del protocolo diagnóstico de esta alteración bioquímica, debería incluirse el estudio serológico de la enfermedad celiaca.

Como conclusión, queremos destacar en este trabajo, la necesidad de llevar a cabo estudios familiares amplios, cuando se diagnostica un caso de enfermedad celiaca, puesto que el riesgo no sólo se limita a los familiares más próximos. Por otra parte, nos gustaría llamar la atención sobre la frecuente aparición de formas atípicas o asintomáticas entre los familiares de pacientes celiacos. Con todo ello, es posible aumentar el número de pacientes diagnosticados de enfermedad celiaca, dentro de un grupo de riesgo ya bien caracterizado. 